\title{
Effect of Leafy and Leafless Greenwood, Softwood and Hardwood Cuttings Success of Garcinia kola (Heckel)
}

\author{
Jonas Patrick Dao, ${ }^{1 *}$ (D), Kouakou Laurent Kouakou1,3, Camille Kouakou1, \\ Mamadou Cherif ${ }^{2}$, Mahamadi Hamed Ouedraogo ${ }^{4}$, Kouame Kevin Koffi ${ }^{3}$, Irié Arsène Zoro Bi ${ }^{3}$ \\ ${ }^{1}$ Training and Research Unit of Sciences of Nature, Laboratory of Biology and Improvement of Plant Production, Nangui \\ Abrogoua University, Abidjan, Côte d'Ivoire \\ ${ }^{2}$ Training and Research Unit of Biosciences, Plant Physiology Laboratory, Felix Houphouët Boigny University, Abidjan, Côte \\ d'Ivoire \\ ${ }^{3}$ Phytotechnical Unit and Genetic Improvement, Training and Research Unit of Sciences of Nature, Nangui Abrogoua University, \\ Abidjan, Côte d'Ivoire \\ ${ }^{4}$ Training and Research Unit of Life and Earth Sciences, Biosciences Laboratory; Genetics and Plant Breeding, Joseph Ki-Zerbo \\ University, Ouagadougou, Burkina Faso \\ Email: *daojonas07@gmail.com
}

How to cite this paper: Dao, J.P., Kouakou, K.L., Kouakou, C., Cherif, M., Ouedraogo, M.H., Koffi, K.K. and Bi, I.A.Z. (2020) Effect of Leafy and Leafless Greenwood, Softwood and Hardwood Cuttings Success of Garcinia kola (Heckel). Agricultural Sciences, 11, 897-911.

https://doi.org/10.4236/as.2020.1110058

Received: August 14, 2020

Accepted: October 13, 2020

Published: October 16, 2020

Copyright $\odot 2020$ by author(s) and Scientific Research Publishing Inc. This work is licensed under the Creative Commons Attribution International License (CC BY 4.0).

http://creativecommons.org/licenses/by/4.0/

\section{(c) (i) Open Access}

\begin{abstract}
Garcinia kola Heckel, called "petit cola" in Côte d'Ivoire and "bitter kola" in Nigeria, is a Non-Timber Forest Product of great socioeconomic importance. Unfortunately, this species is threatened due to overexploitation and deforestation. This study tested the effect of leaf area on stem cuttings to regenerate vegetatively in a non-mist poly-propagator without using exogenous hormones. Three stem cuttings types: greenwood, softwood and hardwood (12 $15 \mathrm{~cm}$ in length) were collected from 24-month years old seedlings. The two top leaves of each cutting type were conserved at different leaf area: $0 \mathrm{~cm}^{2}$, $28.25 \mathrm{~cm}^{2}, 56.5 \mathrm{~cm}^{2}, 84.75 \mathrm{~cm}^{2}$ and $113 \mathrm{~cm}^{2}$ (entire leaf area). Observations were made on rooting, sprouting and leafing abilities of cuttings depending to treatments applied. Results showed that all cutting types have presented good ability to shooting and rooting. Cuttings with $113 \mathrm{~cm}^{2}$ leaf areas presented the best rooting $(94.44 \% \pm 2.42 \%)$ and shouting $(95.55 \% \pm 2.42 \%)$ percentage and longest primary root length $(12.03 \pm 0.50 \mathrm{~cm})$. Hardwood, softwood and greenwood cuttings with $113 \mathrm{~cm}^{2}$ leaf area had the best rooting percentage $(96.66 \% \pm 3.33 \%, 96.66 \% \pm 5.77 \%$ and $90.00 \% \pm 5.77 \%$ respectively). The longest primary root length $(13.50 \pm 0.97 \mathrm{~cm})$ was observed to greenwood cuttings with $113 \mathrm{~cm}^{2}$ leaf area. Regenerated plants in the forest presented well survival percentage (96.66\%). This study shows that it is possible to regenerate entire plants by cuttings without using external hormones in
\end{abstract}


non-mist poly-propagator.

\section{Keywords}

Garcinia kola Heckel, Leaf Area, Non-Mist Poly-Propagator, Stem Cuttings, Vegetative Propagation

\section{Introduction}

The domestication of forest trees as new crops is now recognized for their ability to transform tropical land used by improving agricultural production/food security; increasing farmers' income and their well-being [1] [2]. Garcinia kola belongs to the Clusiaceae family and it's endemic in the humid lowland rainforest vegetation of the West and Central African [3]. Like many other forest trees, $G$. kola is produced traditionally and constitutes an important commercial product [4] [5]. For example, its fruits, edible nuts and roots have medicinal importance and its branches with bactericidal properties, are used as chewing sticks [6]. The seed contains a chemical called kolaviron, a biflavonoïdes which has antimalarial properties [7]. Seed extracts are also used in the treatment of diarrhoea [8], bronchitis and throat infections [9] and anti-sickling activities [10].

In Côte d'Ivoire, seeds are recently used in breweries industries to make soda or energy drink. The species has a high local market demand or export [11] [12]. These several demands increase the level of the species exploitation. But its overexploitation is currently done on the natural population of species. This situation coupled with deforestation, limits seriously the natural regeneration of the species [13]. Several studies showed that $G$. Kola has a threatened status in central and west Africa tropical forest [12] [14] [15].

G. kola can only regenerate from seed (kernel) in natural environments. Unfortunately, the low germination of its seeds has been noticed as a major problem in natural regeneration or for huge quantity of seedlings production, due to their high level of dormancy [3] [11] [16]. To promote the cultivation of G. kola, a lot of works have been led to investigate seed germination [3] [11] [16] [17]. Different methods were used for the seed's dormancy breaking, such as stratification [18] and soaking in Gibberellic acid solution [11] to obtain over than 96\% germination. However, these technologies are not available to farmers. Also, reproduction by seeds (sexual reproduction) still does not allow individuals (hybrids) identical to the mother plant to be obtained. In fact, this hybrid plant can have different characters from those of the mother plant [19].

Another problem is seeds availability to use it for seedlings production, since the seeds are commonly used for local and international trade.

Besides, few experiments were also conducted on vegetative propagation to investigate grafting [20] and juvenile stem cuttings [21]. Unlike plants of the Aceraceae family (Palm), almost all plants can reproduce by macro-cuttings due 
to the presence of axillary buds on twigs and stems [22] [23]. Indeed, vegetative propagation by cuttings is a technique of conform reproduction of mother plant, unlike sexual reproduction. In addition, this technique can induce an early fruiting of plants [24].

Difficult rooting ability of stem cuttings collected from branches of mature trees of $G$. kola was reported by [21]. Other Garcinia species (Garcinia pedunculata Roxb. ex Buch.-Ham. and Garcinia morella (Gaertn.) Desr.) were successful propagated by using juvenile stem cutting from seedlings [25]. But little information was given about the role of leaf and cutting physiological state on rooting of stem cuttings of Garcinia. kola. However, many indigenous trees species were propagated by leafy stem cutting [24]. According to several authors, successful propagation of leafy stem cuttings depends on many factors and they interactions such as plant species, rooting media, leaf area, cutting physiological state and propagation environment [24] [26] [27] [28]. In addition, most studies investigated on rooting ability of stem cutting position. In case of $G$. kola, softwood cuttings presented high rooting ability [21]. For other trees such as Dalbergia sissoo [29] and Dalbergia melanoxylon [30] the best rooting ability were recorded on cuttings from basal and middle position than those from apical position of stock shoot. Effect of leaf on rooting ability of stem cuttings has been reported in many trees [31] [32] and noted that photosynthesis activities depend of the optimum leaf area.

In a survey of farmer's species for agroforestry, $G$. kola was identified as one of the top priority species for domestication in the humid lowlands of West Africa [33]. To domesticate species like $G$. kola as new crops, vegetative propagation protocols have been developed [24]. So, these protocols make possible to multiply and select the best seedlings and used them as horticultural cultivars. Thus, [34] have developed non-mist poly-propagators for the rooting of stem cuttings for the use of farmers in remote rural areas when domesticating indigenous fruit and nut trees. This rapid clonal multiplication approach to domestication is considered ideal for the rapid multiplication of a species under threat and also allows the propagation of selected trees with superior characteristics. In G. kola, vegetative propagation studies have focussed on stem and root cuttings [21]. These studies have indicated that the greatest success is achieved when cuttings are treated with $2.5 \mathrm{~g} / \mathrm{l}$ of indole butyric acid (IBA). To promote the domestication of $G$. kola in agroforestry, it will be necessary to further develop efficient methods and techniques of clonally propagating $G$. kola which are easily transferable to farmers and which are affordable given the cost of phytohormones.

The present study, done under non-mist poly-propagator system, fits in this context. The objective of study was to develop vegetative propagation methods testing the hypothesis that successful rooting and sprouting of leafy stem cuttings can be achieved by optimising the level of stem lignification and the lamina area of the leaf. 


\section{Materials and Methods}

\subsection{Experimental Site}

The experiments were carried out from July 2016 to February 2017 in Abidjan, Côte d'Ivoire, at University Nangui Abrogoua research station $\left(05^{\circ} 23^{\prime} \mathrm{N}\right.$, $\left.04^{\circ} 00^{\prime} \mathrm{W}\right)$. The experimental station is located in the forest zone where the rainfall pattern is bimodal with four distinct seasons, two dry (from December to March and from July to August), and two wet (from April to June and from September to November). Mean annual rainfall varies between 1800 - $2000 \mathrm{~mm}$. Mean monthly temperature varies between $27^{\circ} \mathrm{C}$ and $30^{\circ} \mathrm{C}$, whereas mean relative humidity ranges between $70 \%-84 \%[21]$.

\subsection{Plant Material}

The plant material consists of stem cuttings collected from seedlings (24 months old and $50 \mathrm{~cm}$ in height) obtained in nursery at University Nangui Abrogoua research station.

\subsection{Methods}

\subsubsection{Cuttings Preparation}

Seedlings were watered 24 hours before the cuttings were taken. Stems were excised in the morning (07.00-08.00 am) to $2 \mathrm{~cm}$ above the collar region from the seedlings with a pair of disinfected secateurs. Stem cuttings were of three types 1) the apical part or greenwood cuttings (Figure 1(a)), 2) central part or softwood cuttings (Figure 1(b)) and 3) basal part or hardwood cuttings (Figure $1(\mathrm{c})$ ). The average length of the three types of cuttings ranged from $12-15 \mathrm{~cm}$. The average diameter of greenwood, softwood and hardwood cuttings was $1.0 \pm$ $0.2 \mathrm{~cm}, 1.2 \pm 0.5 \mathrm{~cm}$ and $1.5 \pm 0.5 \mathrm{~cm}$, respectively. Each cutting had at least two axillary buds. The top two leaves of each cutting type were conserved at $0 \%$, $25 \%, 50 \%, 75 \%$ and $100 \%$ of the intact leaf area corresponding to $0,28.25,56.5$, 84.75 and $113 \mathrm{~cm}^{2}$ (entire leaf area). The leaf area was calculated using templates cut from graph papers according to [27].

\subsubsection{Experiment Design and Treatments}

The experiment was laid out in a randomized block design in a non-mist poly-propagator modified from the design of [21] [24] [34]. The non-mist poly-propagator measuring $250 \times 120 \times 80 \mathrm{~cm}$ (Length $\times$ width $\times$ height) were placed in nursery shaded by palm fronds and canes of bamboo to prevent excessive temperatures. This non-mist poly-propagator was a wooden frame enclosed in clear polythene. The base, covered with a thin layer of fine sea sand to present the polythene from being performed by the stones followed by successive layers of small stones and then covered with the rooting media. This rooting media consisted of mixed substrate resulting from a mixture of soil taken from a fallow with vegetation mainly composed of Chromolaena odorata (L.) and Panicum maximum (Jacq.) for the role of these plants in maintaining soil fertility. And a 
sandy soil from river in a proportion 1:1 (V/V) [21]. The mixed substrate $(\mathrm{pH}$ 5.5) were treated with a fungicide (mancozeb Callivoire-Abidjan $880 \mathrm{~W}$ in water at $15 \mathrm{~g} \cdot \mathrm{l}^{-1}$ ) according to the method of [21].

Two factors were tested 1) the cutting type (greenwood, softwood and hardwood) and 2) leaf area $\left(0,28.25,56.5,84.75\right.$ and $\left.113 \mathrm{~cm}^{2}\right)$. Fifteen treatments were applied ( 3 cutting types $\times 5$ leaf areas). For each treatment, 60 cuttings were arranged in three replicates (20 cuttings per replicate). Cuttings were inserted to a depth of $3 \mathrm{~cm}$ in the rooting media with a spacing of $5 \mathrm{~cm}$ from eacth other (Figure 2). After planting, cuttings were watered and the non-mist poly-propagator was covered with clear polythene to maintain high humidity around the cuttings and allow the penetration of light into the propagator (Figure 3). The average temperature and relative humidity registered in the non-mist poly-propagator were $28^{\circ} \mathrm{C} \pm 2^{\circ} \mathrm{C}$ and $94 \%$, respectively. The cuttings were sprayed with a fine mist of water once per week because of the high moisture content in this non-mist poly-propagator.

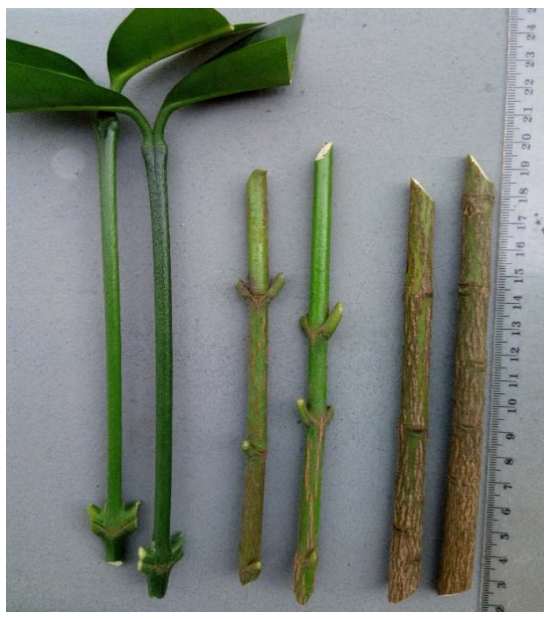

(a)

(b)

(c)

Figure 1. Different types of Garcinia kola cuttings used for propagation; greenwood leafy cuttings with $25 \%$ of leaf area $\left(28.5 \mathrm{~cm}^{2}\right)$ (a), softwood leafless cuttings (b), hardwood leafless cuttings (c).

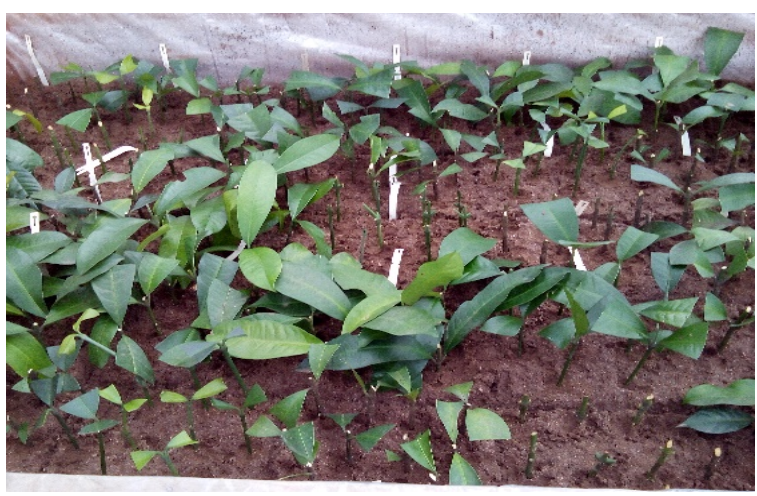

Figure 2. Unrooted cuttings of Garcinia kola planted in non-mist poly-propagator. 


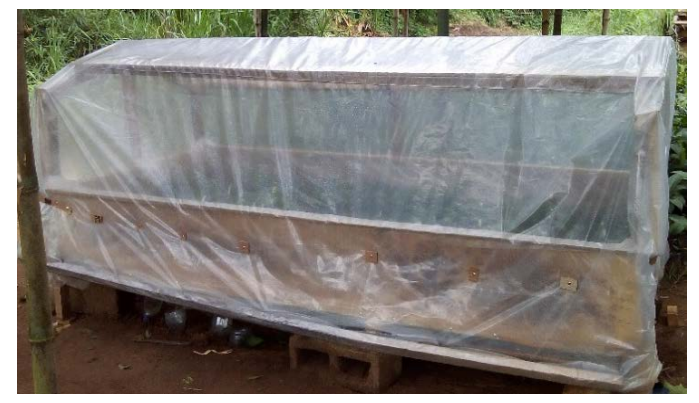

Figure 3. Closed non-mist poly-propagator containing cuttings and placed under shade.

Over a period of 180 days after planting the cuttings, assessments were made on cuttings viability percentage (cuttings remained green and alive, or dead); the percentage of sprouting and rooting, the sprouting and leafing emergence time, the number of primary roots, the length of shoot and the longest root per cutting. Cuttings were considered rooted or sprouted when they have one root or bud exceeding $0.5 \mathrm{~cm}$ in length. To facilitate rooting evaluation, rooted cuttings were taken from substrate carefully and sand was removed. Sprouting was assessed every two days, while rooting was assessed at monthly intervals. Final mean data/percentages were calculated at the end of the experiment.

Rooted cuttings were transferred into plastic bags and placed under the shaded nursery condition for acclimatization. The plants were set under shaded nursery during 18 months.

\subsubsection{Regenerated Plants Growth in Situ}

The experiment was done in June 2018. After acclimatization period under shade nursery some survivals plants were transferred in the relic forest of Nangui Abrogoua University to evaluate their development. Sixty plants were selected and planted in the forest. The spacing between two plants was $10 \mathrm{~m}$. To limit transpiration and water lost, the number of leaves and the top leaves were reduced. Survival percentage, initial and final length, number of leaf and collar diameter were recorded after nine months.

\subsubsection{Data Analysis}

Means values and standard deviations were calculated for each evaluated parameter with respect of cutting type and leaf area. The effect of the different factors and their interaction was evaluated by using analysis of variance (ANOVA). Least significant difference (LSD) multiple range-tests were used to identify differences between means. The Student $t$ test was applied to compare initial and final values of different growth parameters of seedling introduced in the forest.

\section{Results}

\subsection{Effect of Cutting Type on Rooting and Sprouting Ability of Stem Cuttings in Non-Mist Poly-Propagator}

The results of Table 1 show that rooting and shooting ability was significantly 
affected by cutting type $(P<0.05)$. All cutting types present good ability to root. Rooting percentage ranges from $58 \%$ to $63 \%$. The highest rooting percentage was observed to hardwood cutting $(63.33 \% \pm 8.08 \%)$ following by softwood cutting $(62.66 \% \pm 9.53 \%)$. The best primary root number per cutting was observed to hardwood cuttings $(1.65 \pm 0.08)$. The longest primary root was obtained to greenwood cuttings $(11.40 \pm 0.53 \mathrm{~cm})$. Concerning shooting percentage, greenwood and hardwood cuttings presented the best values $(68.00 \% \pm 7.63 \%$ and $68.66 \% \pm 5.42 \%$, respectively). Greenwood cuttings presented the highest shoot number $(2.03 \pm 0.09)$, shoot length $(6.27 \pm 0.33 \mathrm{~cm})$ and leaf number $(7.22 \pm$ $0.37)$.

\subsection{Effect of Leaf Area on Rooting and Sprouting Ability of Stem Cuttings in Non-Mist Poly-Propagator}

Leaf area affected significantly rooting and shooting $(P<0.05)$ while mean primary root number and mean shoot number was not significantly affected (Table 2). Cutting with $113 \mathrm{~cm}^{2}$ leaf area presented the best rooting and shooting percentage $(94.44 \% \pm 2.42 \%$ and $95.55 \% \pm 2.42 \%$, respectively). The mean primary root length increases with increasing of leaf area. The longest primary root was observed to cutting with $113 \mathrm{~cm}^{2}$ leaf area $(12.03 \pm 0.50 \mathrm{~cm})$. The highest secondary root number was observed on cutting with $56.5,84.75$ and $113 \mathrm{~cm}^{2}$ leaf area. The best shoot length $(6.88 \pm 0.40 \mathrm{~cm})$ and the highest leaf number $(7.05 \pm 0.78)$ were observed to cutting with $113 \mathrm{~cm}^{2}$ and $0 \mathrm{~cm}^{2} \%$ leaf area, respectively.

Table 1. Influence of $G$. kola stem cutting type on rooting and shooting ability in non-mist poly-propagator.

\begin{tabular}{|c|c|c|c|c|c|c|c|c|}
\hline Cutting type & $\begin{array}{l}\text { Rooting } \\
\text { (\%) }\end{array}$ & $\begin{array}{l}\text { Shooting } \\
(\%)\end{array}$ & $\begin{array}{l}\text { Mean primary } \\
\text { root number }\end{array}$ & $\begin{array}{c}\text { Mean primary } \\
\text { root Length }(\mathrm{cm})\end{array}$ & $\begin{array}{l}\text { Mean secondary } \\
\text { root number }\end{array}$ & $\begin{array}{c}\text { Mean shoot } \\
\text { number }\end{array}$ & $\begin{array}{l}\text { Mean shoot } \\
\text { length }(\mathrm{cm})\end{array}$ & $\begin{array}{c}\text { Mean leaf } \\
\text { number }\end{array}$ \\
\hline Greenwood & $58.66 \pm 8.50^{\mathrm{b}}$ & $68.66 \pm 5.42^{\mathrm{a}}$ & $1.24 \pm 0.05^{\mathrm{b}}$ & $11.40 \pm 0.53^{\mathrm{a}}$ & $9.94 \pm 0.47^{\mathrm{a}}$ & $2.03 \pm 0.09^{\mathrm{a}}$ & $6.27 \pm 0.33^{\mathrm{a}}$ & $7.22 \pm 0.37^{\mathrm{a}}$ \\
\hline Softwood & $62.66 \pm 9.53^{\mathrm{a}}$ & $66.00 \pm 9.70^{\mathrm{b}}$ & $1.35 \pm 0.06^{\mathrm{b}}$ & $10.41 \pm 0.48^{\mathrm{b}}$ & $9.09 \pm 0.52^{\mathrm{a}}$ & $1.13 \pm 0.03^{c}$ & $5.50 \pm 0.35^{\mathrm{b}}$ & $5.00 \pm 0.25^{\mathrm{b}}$ \\
\hline Hardwood & $63.33 \pm 8.08^{\mathrm{a}}$ & $68.00 \pm 7.63^{\mathrm{a}}$ & $1.65 \pm 0.08^{\mathrm{a}}$ & $9.60 \pm 0.40^{\mathrm{b}}$ & $9.59 \pm 0.45^{\mathrm{a}}$ & $1.28 \pm 0.04^{\mathrm{b}}$ & $5.54 \pm 0.34^{\mathrm{b}}$ & $6.52 \pm 0.27^{\mathrm{ab}}$ \\
\hline
\end{tabular}

QValues (means \pm SD) within a column followed by different superscript letters are significantly different at $P<0.05$.

Table 2. Influence of leaf area on rooting and shooting ability of $G$. kola stem cutting in non-mist poly-propagator.

\begin{tabular}{ccccccccc}
\hline $\begin{array}{c}\text { Leaf area } \\
\left(\mathrm{cm}^{2}\right)\end{array}$ & $\begin{array}{c}\text { Rooting } \\
(\%)\end{array}$ & $\begin{array}{c}\text { Shooting } \\
(\%)\end{array}$ & $\begin{array}{c}\text { Mean primary } \\
\text { root number }\end{array}$ & $\begin{array}{c}\text { Mean primary } \\
\text { root Length }(\mathrm{cm})\end{array}$ & $\begin{array}{c}\text { Mean secondary } \\
\text { root number }\end{array}$ & $\begin{array}{c}\text { Mean shoot } \\
\text { number }\end{array}$ & $\begin{array}{c}\text { Mean shoot } \\
\text { length }(\mathrm{cm})\end{array}$ & $\begin{array}{c}\text { Mean leaf } \\
\text { number }\end{array}$ \\
\hline 0 & $21.11 \pm 7.53^{\mathrm{e}}$ & $32.22 \pm 8.46^{\mathrm{e}}$ & $1.33 \pm 0.16^{\mathrm{a}}$ & $7.02 \pm 0.71^{\mathrm{d}}$ & $6.16 \pm 0.93^{\mathrm{b}}$ & $1.55 \pm 0.16^{\mathrm{a}}$ & $4.22 \pm 0.45^{\mathrm{c}}$ & $7.05 \pm 0.78^{\mathrm{a}}$ \\
28.25 & $35.55 \pm 7.47^{\mathrm{d}}$ & $54.44 \pm 9.14^{\mathrm{d}}$ & $1.50 \pm 0.11^{\mathrm{a}}$ & $6.59 \pm 0.51^{\mathrm{d}}$ & $6.66 \pm 0.84^{\mathrm{b}}$ & $1.60 \pm 0.14^{\mathrm{a}}$ & $4.02 \pm 0.34^{\mathrm{c}}$ & $6.23 \pm 0.54^{\mathrm{b}}$ \\
56.5 & $75.55 \pm 6.89^{\mathrm{c}}$ & $80.00 \pm 6.45^{\mathrm{b}}$ & $1.37 \pm 0.08^{\mathrm{a}}$ & $10.57 \pm 0.49^{\mathrm{c}}$ & $9.77 \pm 0.44^{\mathrm{a}}$ & $1.54 \pm 0.09^{\mathrm{a}}$ & $5.66 \pm 0.35^{\mathrm{b}}$ & $6.51 \pm 0.36^{\mathrm{b}}$ \\
84.75 & $81.11 \pm 2.60^{\mathrm{b}}$ & $75.55 \pm 5.03^{\mathrm{c}}$ & $1.38 \pm 0.06^{\mathrm{a}}$ & $11.01 \pm 0.53^{\mathrm{b}}$ & $9.77 \pm 0.60^{\mathrm{a}}$ & $1.43 \pm 0.08^{\mathrm{a}}$ & $5.67 \pm 0.39^{\mathrm{b}}$ & $5.74 \pm 0.34^{\mathrm{c}}$ \\
113 & $94.44 \pm 2.42^{\mathrm{a}}$ & $95.55 \pm 2.42^{\mathrm{a}}$ & $1.48 \pm 0.00^{\mathrm{a}}$ & $12.03 \pm 0.50^{\mathrm{a}}$ & $10.93 \pm 0.45^{\mathrm{a}}$ & $1.39 \pm 0.07^{\mathrm{a}}$ & $6.88 \pm 0.40^{\mathrm{a}}$ & $6.26 \pm 0.33^{\mathrm{b}}$
\end{tabular}

Values (means $\pm \mathrm{SD}$ ) within a column followed by different superscript letters are significantly different at $P<0.05$. 


\subsection{Combined Effect of Cutting Type and Leaf Area on Rooting and Sprouting Ability of Stem Cuttings in Non-Mist Poly-Propagator}

The combined effect of cutting types and leaf area significantly influenced all the parameters evaluated $(P<0.05)$ (Table 3$)$. All cutting types whatever leaf area presented ability to produce root (Figure 4). Cuttings with $113 \mathrm{~cm}^{2}$ leaf area gave the best rooting percentage, but this was significantly different between cutting type (hardwood $=96.66 \% \pm 3.33 \%$; softwood $=96.66 \% \pm 3.33 \%$ and greenwood $=90.00 \% \pm 5.77 \%)$. The lowest rooting percentage was observed to leafless $\left(0 \mathrm{~cm}^{2}\right)$ cutting for greenwood $(13.33 \% \pm 3.33 \%)$ and softwood $(6.66 \% \pm$ $3.33 \%)$. The highest mean primary root number (1.85) was obtained with hardwood cutting with 28.25 and $56.5 \mathrm{~cm}^{2}$ leaf area. The longest primary root was observed to greenwood cutting with $113 \mathrm{~cm}^{2}$ leaf area $(13.50 \pm 0.97 \mathrm{~cm})$ followed by those of $56.5 \mathrm{~cm}^{2}$ leaf area $(12.00 \pm 0.90 \mathrm{~cm})$. The lowest root length was observed to cutting with 0 and $28.25 \mathrm{~cm}^{2}$ leaf area whatever cutting type. Concerning shooting, all cutting types presented ability to produce shoot and new leaf. Hardwood cutting with $113 \mathrm{~cm}^{2}$ leaf area presented the best shooting percentage $(100.00 \% \pm 0.00 \%)$. Greenwood cutting with 0 to $56.5 \mathrm{~cm}^{2}$ leaf area presented the highest shoot number. The longest shoot was observed to greenwood cutting with $56.5 \mathrm{~cm}^{2}$ leaf area. Greenwood cutting gave the best leaf number. But there is significant difference between leaf area $\left(0 \mathrm{~cm}^{2}\right.$ leaf area $=9.75 \pm 1.03 ; 56.5 \mathrm{~cm}^{2}$ leaf area $=8.52 \pm 0.77)$.

Table 3. Interaction effect of cutting type and leaf area on Garcinia kola stem cutting propagation parameters in non-mist poly-propagator.

\begin{tabular}{|c|c|c|c|c|c|c|c|c|c|}
\hline $\begin{array}{l}\text { Cutting } \\
\text { Type }\end{array}$ & $\begin{array}{l}\text { Leaf area } \\
\qquad\left(\mathrm{cm}^{2}\right)\end{array}$ & $\begin{array}{c}\text { Rooting } \\
\text { (\%) }\end{array}$ & $\begin{array}{c}\text { Shouting } \\
(\%)\end{array}$ & $\begin{array}{l}\text { Mean primary } \\
\text { root number }\end{array}$ & $\begin{array}{l}\text { Mean primary } \\
\text { root Length } \\
(\mathrm{cm})\end{array}$ & $\begin{array}{l}\text { Mean secondary } \\
\text { root number }\end{array}$ & $\begin{array}{c}\text { Mean shoot } \\
\text { number }\end{array}$ & $\begin{array}{l}\text { Mean shoot } \\
\text { length }(\mathrm{cm})\end{array}$ & $\begin{array}{c}\text { Mean leaf } \\
\text { number }\end{array}$ \\
\hline \multirow{5}{*}{ Greenwood } & 0 & $13.33 \pm 3.33^{\mathrm{g}}$ & $46.66 \pm 8.81^{\mathrm{f}}$ & $1.00 \pm 0.00^{\mathrm{e}}$ & $6.12 \pm 1.76^{\mathrm{e}}$ & $6.00 \pm 2.91^{\mathrm{e}}$ & $2.25 \pm 0.47^{\mathrm{a}}$ & $5.50 \pm 132^{c}$ & $9.75 \pm 1.03^{\mathrm{a}}$ \\
\hline & 28.25 & $36.66 \pm 12.01^{\mathrm{e}}$ & $66.66 \pm 8.81^{\mathrm{d}}$ & $1.50 \pm 0.22^{\mathrm{c}}$ & $6.40 \pm 0.79^{\mathrm{e}}$ & $7.70 \pm 1.57^{\mathrm{d}}$ & $2.20 \pm 0.32^{\mathrm{a}}$ & $3.70 \pm 0.77^{\mathrm{e}}$ & $7.40 \pm 1.03^{\mathrm{c}}$ \\
\hline & 56.5 & $73.33 \pm 14.52^{\mathrm{c}}$ & $70.00 \pm 11.54^{\mathrm{d}}$ & $1.14 \pm 0.07^{\mathrm{de}}$ & $12.00 \pm 0.90^{\mathrm{b}}$ & $11.04 \pm 0.82^{\mathrm{a}}$ & $2.19 \pm 0.20^{\mathrm{a}}$ & $7.50 \pm 0.48^{\mathrm{a}}$ & $8.52 \pm 0.77^{\mathrm{b}}$ \\
\hline & 84.75 & $80.00 \pm 5.77^{\mathrm{b}}$ & $70.00 \pm 15.27^{\mathrm{d}}$ & $1.26 \pm 0.09^{\mathrm{d}}$ & $11.47 \pm 0.93^{\mathrm{bc}}$ & $9.43 \pm 0.95^{c}$ & $1.95 \pm 0.19^{\mathrm{b}}$ & $5.71 \pm 0.66^{c}$ & $6.00 \pm 0.62^{\mathrm{d}}$ \\
\hline & 113 & $90.00 \pm 5.77^{\mathrm{a}}$ & $90.00 \pm 5.77^{\mathrm{b}}$ & $1.25 \pm 0.11^{\mathrm{d}}$ & $13.50 \pm 0.97^{\mathrm{a}}$ & $10.92 \pm 0.71^{\mathrm{b}}$ & $1.88 \pm 0.17^{\mathrm{b}}$ & $6.87 \pm 0.65^{\mathrm{b}}$ & $6.81 \pm 0.71^{\mathrm{cd}}$ \\
\hline \multirow{5}{*}{ Softwood } & 0 & $6.66 \pm 3.33^{\mathrm{g}}$ & $6.66 \pm 3.33^{\mathrm{h}}$ & $1.00 \pm 0.00^{\mathrm{e}}$ & $5.50 \pm 3.50^{\mathrm{e}}$ & $5.00 \pm 1.00^{\mathrm{e}}$ & $1.50 \pm 0.50^{\mathrm{ab}}$ & $4.00 \pm 2.00^{\mathrm{d}}$ & $4.50 \pm 2.50^{\mathrm{e}}$ \\
\hline & 28.25 & $43.33 \pm 17.63^{\mathrm{d}}$ & $60.00 \pm 25.16^{\mathrm{e}}$ & $1.30 \pm 0.13^{\mathrm{d}}$ & $6.68 \pm 0.98^{e}$ & $5.23 \pm 1.33^{\mathrm{e}}$ & $1.30 \pm 0.13^{\mathrm{bc}}$ & $3.57 \pm 0.37^{\mathrm{e}}$ & $6.07 \pm 0.62^{\mathrm{d}}$ \\
\hline & 56.5 & $83.33 \pm 8.81^{\mathrm{b}}$ & $90.00 \pm 5.77^{\mathrm{b}}$ & $1.20 \pm 0.08^{\mathrm{d}}$ & $11.34 \pm 0.74^{\mathrm{bc}}$ & $9.20 \pm 0.69^{c}$ & $1.16 \pm 0.07^{\mathrm{c}}$ & $5.28 \pm 0.60^{c}$ & $5.00 \pm 0.33^{\mathrm{e}}$ \\
\hline & 84.75 & $83.33 \pm 3.33^{b}$ & $76.66 \pm 3.33^{c}$ & $1.30 \pm 0.10^{\mathrm{d}}$ & $11.35 \pm 0.98^{\mathrm{bc}}$ & $10.40 \pm 1.23^{\mathrm{b}}$ & $1.00 \pm 0.00^{c}$ & $5.50 \pm 0.57^{c}$ & $4.65 \pm 0.70^{e}$ \\
\hline & 113 & $96.66 \pm 3.33^{\mathrm{a}}$ & $96.66 \pm 3.33^{b}$ & $1.59 \pm 0.14^{\mathrm{b}}$ & $11.03 \pm 0.92^{\mathrm{c}}$ & $10.18 \pm 0.87^{c}$ & $1.11 \pm 0.06^{\mathrm{c}}$ & $6.74 \pm 0.81^{b}$ & $4.77 \pm 0.43^{\mathrm{e}}$ \\
\hline \multirow{5}{*}{ Hardwood } & 0 & $43.33 \pm 16.66^{\mathrm{d}}$ & $43.33 \pm 16.66^{\mathrm{f}}$ & $1.50 \pm 0.23 b^{c}$ & $7.58 \pm 0.79^{\mathrm{d}}$ & $6.41 \pm 0.91^{\mathrm{de}}$ & $1.33 \pm 0.14^{\mathrm{bc}}$ & $3.83 \pm 0.44^{e}$ & $6.58 \pm 0.94^{\mathrm{d}}$ \\
\hline & 28.25 & $26.66 \pm 12.01^{\mathrm{f}}$ & $36.66 \pm 6.66^{g}$ & $1.85 \pm 0.26^{\mathrm{a}}$ & $6.71 \pm 0.71^{\mathrm{e}}$ & $7.85 \pm 1.35^{\mathrm{d}}$ & $1.28 \pm 0.18^{\mathrm{bc}}$ & $5.31 \pm 0.55^{\mathrm{c}}$ & $4.85 \pm 1.33^{\mathrm{e}}$ \\
\hline & 56.5 & $70.00 \pm 15.27^{c}$ & $80.00 \pm 15.27^{c}$ & $1.85 \pm 0.22^{\mathrm{a}}$ & $8.12 \pm 0.69^{\mathrm{d}}$ & $9.15 \pm 0.74^{c}$ & $1.35 \pm 0.10^{b c}$ & $4.22 \pm 0.54^{\mathrm{d}}$ & $6.30 \pm 0.51^{\mathrm{d}}$ \\
\hline & 84.75 & $80.00 \pm 5.77^{\mathrm{b}}$ & $80.00 \pm 5.77^{c}$ & $1.58 \pm 0.13^{\mathrm{b}}$ & $10.29 \pm 0.87^{c}$ & $9.58 \pm 1.00^{c}$ & $1.29 \pm 0.09^{\mathrm{bc}}$ & $5.77 \pm 0.76^{c}$ & $6.41 \pm 0.42^{\mathrm{d}}$ \\
\hline & 113 & $96.66 \pm 3.33^{\mathrm{a}}$ & $100.00 \pm 0.00^{\mathrm{a}}$ & $1.58 \pm 0.16^{\mathrm{b}}$ & $11.58 \pm 0.68^{\mathrm{b}}$ & $11.65 \pm 0.76^{\mathrm{a}}$ & $1.20 \pm 0.07^{\mathrm{bc}}$ & $7.03 \pm 0.68^{\mathrm{b}}$ & $7.13 \pm 0.49^{c}$ \\
\hline
\end{tabular}

Values (means $\pm \mathrm{SD}$ ) within a column followed by different superscript letters are significantly different at $P<0.05$. 


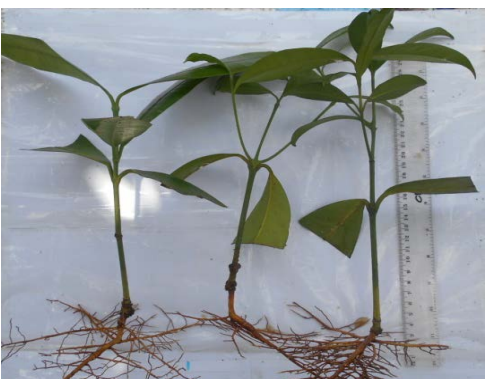

(a)

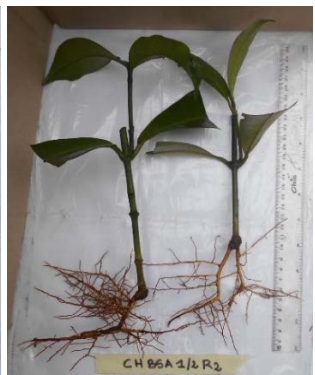

(b)

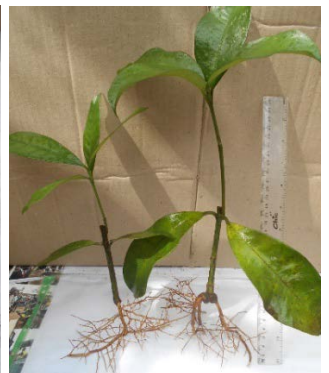

(c)

Figure 4. Rooted Garcinia kola cuttings: (a) greenwood rooted cuttings with $56.5 \mathrm{~cm}^{2}$ leaf area; (b) softwood rooted cuttings with $56.5 \mathrm{~cm}^{2}$ leaf area and (c) hardwood rooted cuttings with $113 \mathrm{~cm}^{2}$ leaf area.

Rooted cuttings transferred under shade nursery for acclimation presented $100 \%$ survival percentage and growth in nursery during 18 months (Figure 5).

\subsection{Regenerated Plants Survival in Situ}

Regenerated plants after acclimatization presented 100\% survival in nursery. After a period of nine months the regenerated plants introduced into the forest presented higher survival percentage (96.66\%). Regenerated plants have presented ability to growth in the forest (Figure 6). The mean of initial and a final value for a period of nine months, range to $52.42 \pm 13.09$ to $55.08 \pm 13.86 \mathrm{~cm}$ for plant height. The mean number of leaf range to $5.28 \pm 1.97$ to $10.35 \pm 6.73$ and the collar diameter range to $9.44 \pm 2.93$ to $10.09 \pm 2.88 \mathrm{~mm}$ (Table 4).

\section{Discussion}

The different cuttings types from $G$. kola seedlings presented good ability on rooting and shooting. Rooting percentage increases from greenwood to hardwood cutting. The best rooting percentage and mean primary root number per cutting observed with hardwood cuttings is probably due to the high-level content of carbohydrates or food reserves [35]. However, these results with G. kola differ to some extent from the generally expected norm in which cuttings from the top of the shoot have an inherently greater rooting ability [24]. Unlike the situation in many other species, this can be explained to some extent by the relatively constant cutting length in the present study whereas many other species like Triplochiton scleroxylon K. Schum. which have longer internodes at top of their shoots [36]. Generally, longer stem cuttings from juvenile shoots have greater capacity for rooting. This can be explained by their greater storage capacity for current assimilates in the propagator before the emergence of new roots [30]. [36] also found some evidence that storage capacity was determined by stem thickness (cutting diameter). In the present study, the successful rooting of hardwood cutting can be due to their large diameter. Similar results were noticed by [37] on vegetative propagation of Ficus roxburghii Wall. These authors noticed that cuttings with large diameter presented higher sprouting and rooting 
ability due to their more food reserves in these cuttings. According to [38], the sprouting of cutting depends on food reserves available within the cuttings in vegetative propagation.

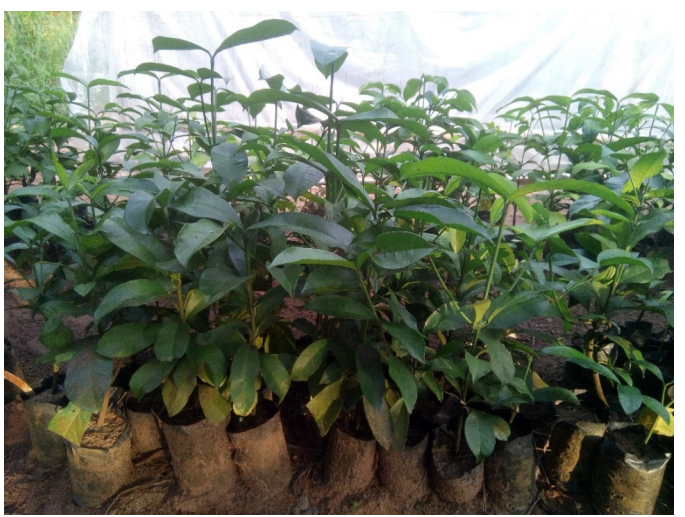

Figure 5. Seedlings of $G$. kola regenerated in non-mist poly-propagator by stem cuttings and acclimatized in shade nursery.

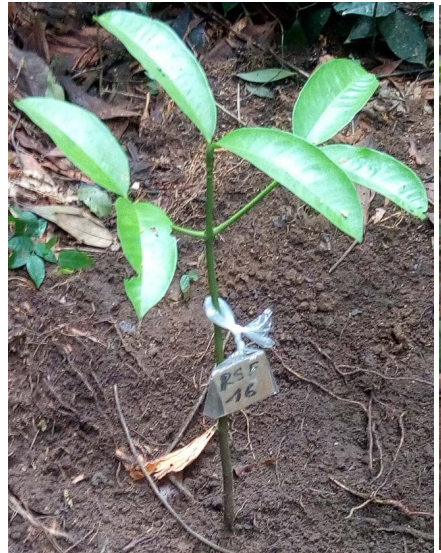

(a)

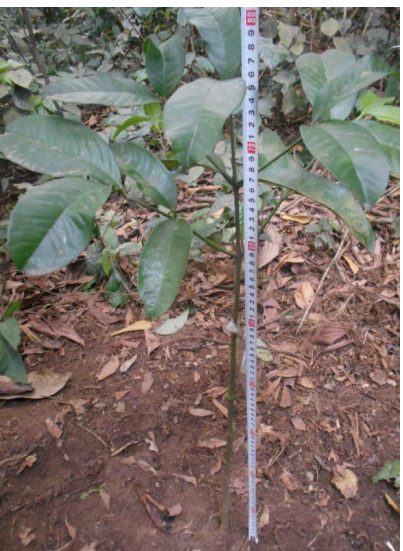

(b)

Figure 6. Regenerated Garcinia kola plant planted in the forest: (a) plant introduce in forest (b) plant growth in the forest after nine months.

Table 4. Comparison of means values of growth parameters of young $G$. kola plant in situ nine months after planting.

\begin{tabular}{ccccc}
\hline \multirow{2}{*}{ Parameters } & Times & Means & \multicolumn{2}{c}{ Statistics } \\
\cline { 4 - 5 } & & & $t$ & $P$ \\
\hline Plant height $(\mathrm{cm})$ & Initial & $52.42 \pm 13.33$ & 4.443 & 0.000 \\
& Final & $55.08 \pm 14.12$ & & \\
Collar diameter $(\mathrm{mm})$ & Initial & $9.44 \pm 2.98$ & 7.213 & 0.000 \\
& Final & $10.09 \pm 2.94$ & & \\
Number of leaves & Initial & $5.28 \pm 2.01$ & 4.345 & 0.000 \\
& Final & $10.35 \pm 6.85$ & & \\
Number of ramifications & Initial & $0.00 \pm 0.00$ & 7.481 & 0.000 \\
& Final & $2.17 \pm 1.54$ & & \\
\hline
\end{tabular}


Regarding shooting percentage, mean shoot number per cutting, mean shoot length and mean leaf number per cutting, the best value observed to greenwood cutting is due to it physiological state. Three or two shoots sprouts on the apical part of the cutting. While, one or two axillaries buds' sprouts on the other cutting type.

Rooting and shooting percentage, mean primary root length, mean secondary root number and mean shoot length enhance with increasing of leaf area. The best values observed to cutting with $113 \mathrm{~cm}^{2}$ leaf area followed by those of 84.75 $\mathrm{cm}^{2}$ leaf area, can be explained by the higher photosynthesis activities of these cuttings which produce carbohydrates and provide a source of energy essential for root emission [39]. The results of the present study with $G$. kola are conform to existing reports on the rooting of stem cuttings in other tropical tree species, such as: Triplochiton scleroxylon [26], Cordia alliodora (Ruiz \& Pavon) [40], Lovoa trichilioides Harms [41] in terms of the very important role of the leaf on cutting propagation. But the results of G. kola differ of those of Shorea leprosula Roxb. ex C.F. Gaerth which stem cuttings rooting decrease with increasing of leaf area [42].

Combined effect of cutting type and leaf area significantly influenced all the rooting and shooting parameters. The best rooting and shooting percentage of cutting with $113 \mathrm{~cm}^{2}$ leaf area followed by those of $84.75 \mathrm{~cm}^{2}$ and $56.5 \mathrm{~cm}^{2}$ leaf area whatever cutting type can be explained by the high level of photosynthesis activities which produce important quantities of carbohydrates for root formation and elongation. Investigations on the role of the leaf in the rooting process have indicated that rooting ability is maximised when severed cuttings are photosynthetically active and producing assimilates for root development and elongation of the root primordia in the absence of water stress [43].

According to [24], the factors determining the rooting and sprouting of leafy softwood cuttings are very different, depending on photosynthates produced in the propagation bed, while hardwood cuttings depend on the hydrolysis and availability of carbohydrates stored within the stem tissues. Vegetative propagation of $G$. kola by stem cuttings can be highly associated with presence of leaves which produce significant level of endogenous auxins and provide more stimuli on the base of cutting to promote rooting without using exogenous rooting hormone application.

The best mean root number per cutting observed on hardwood cutting with 28.25 and $56.5 \mathrm{~cm}^{2}$ leaf area suggested that these leaf areas can promote root number. The best mean primary root length observed to greenwood cuttings with $113 \mathrm{~cm}^{2}$ leaf area suggested that this leaf area produce sufficient carbohydrates, hormones and co-factors for root elongation. The lowest primary root length of leafless cutting and cutting with $28.25 \mathrm{~cm}^{2}$ leaf area shows the importance of the leaf on $G$. kola cutting propagation. During rooting process, shooting and leafing contribute to enhance rooting. In case of $G$. kola, shoot developed first and produce endogenous rooting hormones which come down on the 
base of cuttings. The importance of leaves and new shoots in cuttings relies on the fact that these organs produce plant hormones, such as indoleacetic acid, and rooting cofactors, both essential for adventitious root formation which moves to the base of cutting to promote root initiation [44]. Rooting process starts by the callus formation on the base of the cutting.

The well survival percentage of regenerated plants and its growth in the forest may be due to its vigour. The regenerated plants presented for those cuttings two primary roots which promote the consolidation of the plant. The rooting quality and the high number of secondary roots promote well nutrition and growth activation. On the other end, the well survival rate can be explained by the best adaptation of regenerated plants of the climatic conditions of the forest. This result is essential for the species biodiversity conservation through its introduction in the forest. The cultivation of the species should be possible by using regenerated plants from cuttings.

\section{Conclusion}

This study indicates that regeneration of $G$. kola by seedling from stem cuttings is possible and this was not requiring necessary using exogenous hormones and sophisticated equipment. Non-mist poly-propagator provides well conditions for stem cuttings propagation success. Greatest success was achieved using hardwood cuttings with $113 \mathrm{~cm}^{2}$ leaf area. Further work should seek the optimal conditions for large-scale production of selected $G$. kola cultivars for cultivation by local farmers. Such conditions are appropriate for use in remote locations in tropical countries, even without purchased rooting hormones. The best survival rate and growth of regenerated plants in forest represent an important step for the species cultivation and domestication through agroforestry systems.

\section{Acknowledgements}

This study was funded by the International Foundation for Science (IFS), Project IFS Garcinia (D/5274-2).

\section{Conflicts of Interest}

The authors declare no conflicts of interest regarding the publication of this paper.

\section{References}

[1] Leakey, R.R.B., Tchoundjeu, Z., Schreckenberg, K., Shackleton, S. and Shackleton, C. (2005) Agroforestry Tree Products (AFTPs): Targeting Poverty Reduction and Enhanced Livelihoods. International Journal of Agricultural Sustainability, 3, 1-23. https://doi.org/10.1080/14735903.2005.9684741

[2] Leakey, R.R.B. (2014) Agroforestry-Participatory Domestication of Trees. In: Van Alfen, N., Ed., Encyclopedia of Agriculture and Food Systems, Elsevier Publishers, San Diego, 253-269. https://doi.org/10.1016/B978-0-444-52512-3.00025-5

[3] Yakubu, F.B., Bolanle, O.J., Ogunade, O.J. and Yahaya, D.K. (2014) Effects of Water 
Soaking and Light on the Dormancy of Garcinia kola (Heckel) Seeds. European Journal of Forest Research, 2, 17-26.

[4] Akoègninou, A., Van der Burg, W.J. and Van der Maesen, L.J.G. (2006) Flore Analytique du Bénin. Backhuys Publisher, Wageningen, 476.

[5] Kouame, N.M.T., Ake, C.B., Mangara, A. and N'Guessan, K. (2016) Analyse de l'intérêt Socio-Economique des graines de Garcinia kola Heckel (Clusiaceae) dans la commune de Koumassi (Abidjan), Côte d'Ivoire. International Journal of Biological and Chemical Sciences, 10, 2587-2595. https://doi.org/10.4314/ijbcs.v10i6.15

[6] Adegboye, M.F., Akinpelu, D.A. and Okoh, A.I. (2008) The Bioactive and Phytochemical Properties of Garcinia kola (Heckel) Seed Extract on Some Pathogens. African Journal of Biotechnology, 7, 3934-3938.

[7] Oluwatosin, A., Tolulope, A., Ayokulehin, K., Patricia, O., Aderemi, K. and Catherine, F. (2014) Anti-Malarial Potential of Kolaviron a Biflavonoid from Garcinia kola Seeds, against Plasmodium berghei Infection in Swiss Albino Mice. Asian Pacific Journal of Tropical Medicine, 7, 97-104.

https://doi.org/10.1016/S1995-7645(14)60003-1

[8] Braide, V.B. (1991) Antihepatotoxic Biochemical Effects of Kolaviron, a Biflavonoid of Garcinia kola Seeds. Phytotherapy Research, 5, 35-37. https://doi.org/10.1002/ptr.2650050110

[9] Adesina, S.K., Gbile, Z.O., Odukoya, O.A., Akinwusi, D.D., Illoh, H.C. and Yeola, A.A. (1995) Survey of Indigenous Useful Plants of West Africa with Special Emphasis on Medicinal Plants and Issues Associated with Management. The United Nations Programme on Natural Resources in Africa, 84-85.

[10] Adejumo, O.E., Ayoola, M.D., Kolapo, A.L., Orimoyegun, V.O. and Olatunji, P.O. (2011) Anti-Sickling Activities of Extracts of Leaf, Seed and Seed Pod of Garcinia kola Heckel. African Journal of Pharmacy and Pharmacology, 5, 48-52. https://doi.org/10.5897/AJPP10.052

[11] Kouakou, L.K., Kouakou, C., Koffi, K.K., Dao, J., Beugré, M.M., Baudoin, J.P. and Zoro Bi, I.A. (2016) Effect of Mechanical Scarification and Gibberellins $\left(\mathrm{GA}_{3}\right)$ on Seed Germination and Growth of Garcinia kola (Heckel). Journal of Applied Biosciences, 103, 9811-9818.

[12] Amadu, J. and Aida, C.S. (2017) Priority Indigenous Fruit Trees in the African Rainforest Zone: Insights from Sierra Leone. Genetic Resources and Crop Evolution, 64, 745-760. https://doi.org/10.1007/s10722-016-0397-9

[13] Codjia, S., Aoudji, A., Koura, K. and Ganglo, J.C. (2018) Systèmes agroforestiers à Garcinia kola Heckel au Sud-Est du Bénin: Distribution géographique, connaissances endogènes et retombées financières. European Scientific Journal, 14, 188-208. https://doi.org/10.19044/esj.2018.v14n12p188

[14] Cheek, M. (2004) Garcinia kola. The IUCN Red List of Threatened Species 2004: e.T34715A9884648.

[15] Ouattara, D., Vroh Bi, T.A., Kpangui, K.B. and N'Guessan, K.E. (2013) Diversité végétale et valeur pour la conservation de la réserve botanique d'Agbaou en création, Centre-ouest, Côte d'Ivoire. Journal of Animal \&Plant Sciences, 20, 3034-3047.

[16] Agyili, J., Sacande, M., Koffi, E. and Peprah, T. (2007) Improving the Collection and Germination of West African Garcinia kola Heckel Seeds. New Forest, 34 , 269-279. https://doi.org/10.1007/s11056-007-9054-7

[17] Koffi, E.K., N’Guessan, A.K., Kouame, C.N., Kouassi, M.K. and Kahia, J.W. (2015). Possibility of Using the Intermediate Mature Stage of Garcinia kola Heckel Seeds to 
Shorten the Germination Time. African Journal of Agricultural Research, 10, 4762-4769. https://doi.org/10.5897/AJAR2015.9995

[18] Dadjo, C., Nyende, A.B., Kahia, J. and Assogbadjo, A.E. (2019) Effect of Storage Temperature and Dormancy Breaking Pre-Treatments on Germination and Early Seedling Growth of Garcinia kola (Heckel): A Threatened Medicinal Fruit Tree in Benin. Forest Science and Technology, 15, 173-179. https://doi.org/10.1080/21580103.2019.1646673

[19] Mudge, K.W. and Brennan, E.B. (1999) Clonal Propagation of Multipurpose and Fruit Trees Used in Agroforestry. In: Buck, L.E., Lassoie, J.P. and Fernandes, E.C.M., Eds., Agroforestry in Sustainable Agricultural Systems, CRC Press, New York, 157-190.

[20] Yakubu, F.B., Adejoh, O.P., Ogunade, J.O. and Igboanugo, A.B.I. (2014) Vegetative Propagation of Garcinia kola (Heckel). World Journal of Agricultural Sciences, 10, 85-90.

[21] Kouakou, K.L., Dao, J.P., Kouassi, K.L., BeugrE, M.M., KonE, M., Baudoin, J.P. and Zoro Bi, I.A. (2016) Propagation of Garcinia kola (Heckel) by Stem and Root Cuttings. Silva Fennica, 50, Article ID: 1588. https://doi.org/10.14214/sf.1588

[22] Tomlinson, P.B. (1990) The Structural Biology of Palms. Clarendon Press, Oxford, 477.

[23] Sunderland, T.C.H. (2001) The Taxonomy, Ecology and Utilisation of African Rattans (Palmae: Calamoideae). Doctor of Phylosophy (PhD), University College London, London, 357.

[24] Leakey, R.R.B. (2014) Plant Cloning: Macropropagation. In: Van Alfen, N., Ed., Encyclopedia of Agriculture and Food Systems, Elsevier Publishers, San Diego, 349-359. https://doi.org/10.1016/B978-0-444-52512-3.00223-0

[25] Bhuyan, L., Sharma, C.L., Singh, B. and Sharma, M.B. (2017) Vegetative Propagation of Two Important Garcinia Species of Assam, NE India. Journal of Medicinal Plants, 5, 273-277.

[26] Leakey, R.R.B. and Coutts, M.P. (1989) The Dynamics of Rooting in Triplochiton scleroxylon Cuttings: Their Relation to Leaf Size, Node Position, Dry Weight Accumulation, Leaf Water Potential and Carbohydrate Composition. Tree Physiology, 5, 135-146. https://doi.org/10.1093/treephys/5.1.135

[27] Tchoundjeu, Z., Avana, M.L., Leakey, R.R.B., Simons, A.J., Asaah, E., Duguma, B. and Bell, J.M. (2002) Vegetative Propagation of Prunus Africana: Effects of Rooting Medium, Auxin Concentrations and Leaf Area. Agroforestry Systems, 54,183-192. https://doi.org/10.1023/A:1016049004139

[28] Owusu, S.A., Opuni-Frimpong, E. and Antwi-Boasiako, C. (2014) Improving Regeneration of Mahogany: Techniques for Vegetative Propagation of Four African Mahogany Species Using Leafy Stem Cuttings. New Forests, 45, 687-697. https://doi.org/10.1007/s11056-014-9431-y

[29] Husen, A. (2004) Clonal Propagation of Dalbergia sissoo Roxb. by Softwood Nodal Cuttings: Effects of Genotypes, Application of IBA and Position of Cuttings on Shoots. Silvae Genetica, 53, 50-55. https://doi.org/10.1515/sg-2004-0009

[30] Amri, E., Lyaruu, H.V.M., Nyomora, A.S. and Kanyeka, Z.L. (2010) Vegetative Propagation of African Blackwood (Dalbergia melanoxylon Guill. \& Perr.): Effects of Age of Donor Plant, IBA Treatment and Cutting Position on Rooting Ability of Stem Cuttings. New Forests, 39, 183-194.

https://doi.org/10.1007/s11056-009-9163-6 
[31] Leakey, R.R.B. (1985) The Capacity for Vegetative Propagation in Trees. In: Cannell, M.G.R. and Jackson, J.E., Eds., Attributes of Trees as Crop Plants, Institute of Terrestrial Ecology, Abbotts Ripton, 110-133.

[32] Leakey, R.R.B., Newton, A.C. and Dick, J.M.C.P. (1994) Capture of Genetic Variation by Vegetative Propagation: Processes Determining Success. In: Leakey, R.R.B. and Newton, A.C., Eds., Tropical Trees. The Potential for Domestication and the Rebuilding of Forest Resources, HMSO, London, 72-83.

[33] Franzel, S.C., Jaenicke, H. and Janssen, W. (1996) Choosing the Right Trees: Setting Priorities for Multipurpose Tree Improvement. ISNAR Research, Report No. 8. The Hague. International Service for National Agricultural Research, 100.

[34] Leakey, R.R.B., Mesen, J.F., Tchoundjeu, Z., Longman, K.A., Dick, J.Mc.P., Newton, A., Matin, A., Grace, J., Munro, R.C. and Muthoka, P.N. (1990) Low-Technology Techniques for the Vegetative Propagation of Tropical Trees. Commonwealth Forestry Review, 69, 247-257.

[35] Hartmann, H.T., Kester, D.E., Davies, F.T. and Geneve, R.L. (1997) Plant Propagation Principle and Practices. 6th Edition, Prentice-Hall of India Private Limited, New Delhi, 276-328.

[36] Leakey, R.R.B. and Mohammed, H.R.S. (1985) The Effects of Stem Length on Root Initiation in Sequential Single-Node Cuttings of Triplochiton scleroxylon K. Schum. Journal of Horticultural Science, 60, 431-437. https://doi.org/10.1080/14620316.1985.11515648

[37] Rana, R.S. and Sood, K.K. (2011) Effect of Cutting Diameter and Hormonal Application on the Propagation of Ficus roxburghii Wall. Through Branch Cuttings. Annals of Forest Research, 55, 69-84.

[38] Wright, R.C.M. (1975) The Complete Handbook of Plant Propagation. Macmillan, New York.

[39] Veierskov, B. (1988) Relations between Carbohydrates and Adventitious Root Formation. Advances in Plant Sciences Series, 2, 70-78.

[40] Mesén, F., Newton, A.C. and Leakey, R.R.B. (1997) The Effects of Propagation Environment and Foliar Size on the Rooting Physiology of Cordia alliodora (Ruiz \& Pavon) Oken Cuttings. Trees Structure and Function, 11, 404-411. https://doi.org/10.1007/PL00009683

[41] Tchoundjeu, Z. and Leakey, R.R.B. (2001) Vegetative Propagation of Lovoa trichilioides: Effects of Provenance, Substrate, Auxins and Leaf Size. Journal of Tropical Forest Science, 13, 116-129.

[42] Aminah, H., Dick, J. and Grace, J. (1997) Rooting of Shorea leprosula Stem Cuttings Decreases with Increasing Leaf Size. Forest Ecology and Management, 91, 247-254. https://doi.org/10.1016/S0378-1127(96)03857-1

[43] Mesén, F., Leakey, R.R.B. and Newton, A.C. (2001) The Influence of Stockplant Environment on Morphology, Physiology and Rooting of Leafy Stem Cuttings of Albizia guachapele. New Forests, 22, 213-227. https://doi.org/10.1023/A:1015668011884

[44] Blakesley, D., Weston, G.D. and Hall, J.F. (1991) The Role of Endogenous Auxin in Root Initiation. Plant Growth Regulation, 10, 341-353. https://doi.org/10.1007/BF00024593 